DOI: https://doi.org/10.31539/leea.v1i1.31

\title{
AMERICAN HUMOR USED IN AN AMERICAN COMEDY MOVIE THE BOSS
}

\author{
Sastika Seli ${ }^{1}$ \\ STKIP-PGRI Lubuklinggau, South Sumatra, Indonesia \\ Bahya Alfitri ${ }^{2}$ \\ STKIP-PGRI Lubuklinggau, South Sumatra, Indonesia \\ $\underline{\text { rshellee@yahoo.com }}{ }^{1}$
}

Submit, 08-11-2017 Accepted, 30-12-2017 Publish, 30-12-2017

\begin{abstract}
The research aims to describe the functions of humor used in an American comedy movie The Boss. The subject of the research was American comedy movie The Boss. Descriptive-qualitative method was used to conduct the research. Data collection was done through library research and documentation. Data analysis was done through identification, coding, classification and description. The researcher found several findings. Supported by Meyer's theory of joke, there are 6 functions of jokes found in the movie such as to insult someone, to express anger, to tease someone, to relieve tension, to get attention, and to amuse others. The dominant function was differentiation particularly to insult and to express anger (21 times), the second was clarification particularly to relieve tension (humorous lines) and amuse others (15 times), the third was enforcement particularly to tease (18 times), and the last was identification particularly to relieve tension and to get attention (27 times). These functions were also analyzed and discriminated by different setting and participant based on formality and participants distance. According to the analysis, most jokes occurred in informal situation with intimate relationship among the participants and functioned to tease someone and to relieve tension. This finding also proves that American humor is expressed with more slapstick and vulgarity as the characteristic of American humor used in daily communication.
\end{abstract}

Keywords: sociolinguistics, humor, American humor, American comedy movie, the Boss movie 


\section{INTRODUCTION}

Language has social function. It helps us to establish and maintain the relationship. There is a deep relationship between language and society. All of these have been developed and widely known as a field named sociolinguistics. Sociolinguistics interested in explaining why the people speak differently in different social contexts, and they are concerned with identifying the social functions of language and the ways it is used to convey social meaning. Using language appropriately involves knowing the sociolinguistic rules for speaking in a community (Holmes, 2013: 440).

Humor utterances are a form of communication that is ussually shared in social interaction. It plays an important role in everyday life. According to $\mathrm{Hu}$ (2012: 1185), humor is mankind's greatest blessing, it can add interesting elements to the topic of communication, bring happiness and pleasant feeling to people, change a person's mood, and even construct a way to a happy life. Understanding humor in the current situations is extremely required since it could be used to release tiresome, fatigue, and stress. The main aspects of humor are to amuse people, evoke laughter and evoke a good mood which should be the primary aim of every humors situation. The primary functions of humor in conversation are effect that the speaker may achieve directly by using humors segments or texts in his or her discourse (Attardo, 1994: 322). Laughter is a primary indicator of the experience of humor, but it is not the only one. Smiles, grins, or even sudden exhalations can indicate such experience.

Humor is a phenomenon which is influenced by culture (Jie, 2016:395). Whether or not someone gets a humor is determined by their interpretation, filtered by the cultural context. Every society or every culture has its own types of humor that are somehow particular and differ in many aspects. One of the most famous types of humor is American humor, which is known in the world. According to Jie (2016: 397), the American sense of humor is generally more obvious and forward, a bit like Americans themselves. In this research, the researcher chose American humor because their humor tends to be more obvious and less oblique, it has gained success especially in their movies and TV shows.

One of American comedy movies entitled The Boss. The Boss is one of the new American comedy movies which released on April $8^{\text {th }}$, 2016. This is one of the box office movies. It has been nominated in Teen Choice Awards (Seitz, 2016:98). The Boss is the kind of comedy movie that can portray how humor plays an important role in people's daily life, especially for American. This movie presents divergent humorous conversation that may trigger laughter to people who listen to it. It also 
presents some particular functions of American comedy employ in the conversation based on the setting and participants.

Humor analysis can be used to see how individuals (from different levels of the organizational hierarchy) interact with others, especially in terms of humor usage (Romero and Cruthirds, 2006:58). Another fascinating and interesting use of humor analysis is for cross cultural studies. There were some previous researches about humor analyses, for example previous research conducted by Mak (2008:56). Mak's research analyzed the functions of humor and kinds of context are suitable for telling humor. The researcher analyzed the functions of humor throughout Sociolinguistic perspective according to Meyer's and Holmes theory. The research is expected to describe the functions of humor used in different setting and participants in The Boss movie.

\section{LITERATURE REVIEW}

\section{Language and Interaction}

Language is strongly influenced by social factors. They are the participants or the users of language: who are speaking and who they are speaking to; the setting or social context of the interaction, which is related to its users: where they are speaking; the topic, which deals with what is being talked about; and the function of the interaction, which deals with why they are speaking (Holmes, 2013: 9).

\section{Participants of the interaction}

People generally talk differently to children and to adults although some adjust their speech style or "accommodate" more than others. The differences are based on the background of the participant such as, social identity, age, sex, and personal characteristics. There are many kinds of participant, for example family participants (father-son), job participants (boss-employee), and social participants (friend-friend). The participant or speaker may have influence to the language used. Other speakers may have different ways to talk about one topic or issue.

\section{Setting or social context of the interaction}

Every speech community has different varieties from which people select according to the context in which their members are communicating. Different aspects of the social identity of a person are relevant in determining his/her different setting or social context. People need to be concerned with the meaning of their words in the cultural context in which they are normally used. It involves the understanding of the cultural and social situations in which the participants are 
communicating. The people have to know where they are speaking, for examples, when they speak at school or at home, it is different. The people will use formal language when they speak at school or office, and informal language may be chosen when they speak at home or in daily informal conversation. People have to recognize the culture of place when they speak as well.

\section{Topic of the interaction}

People may select a particular variety or code because it makes them easier to discuss a particular topic, regardless of where they are speaking. Each participant of the interaction may have different views from the others concerning with what exactly is being talked about.

\section{Function of the interaction}

The discussions of the ways in which speech functions are expressed in different contexts involve considerations of politeness. The people have to know why they are speaking.

\section{Humor}

Humor is all encompassing category, covering any event or object that elicits laughter, amuses, or is felt to be funny (Attardo, 1994: 4). It is so pervasive while being most enjoyable and pleasant. Humor as amusing communications that produce positive emotions and cognitions in the individual, group, or organization (Romero and Cruthirds, 2006: 58). Humor like all forms of communication requires context to find it amusing. The audience must have certain knowledge, understanding, and values.

Humor has been claimed to emerge in three basic ways in human thought: through perceptions of relieve, incongruity, and superiority (Meyer, 2000: 312)

\section{The Relieve Theory}

According to the Relieve theory, humor results from reducing stress or tension, often suddenly, and allows release of nervous energy. Physiological symptoms are the most important to look at; the emotional reaction is the key. Humor events allow a sudden violation or enjoyment of the idea of violating social norms. Thus, some of our existing tensions, aroused earlier, are released, and this feeling of relieve creates the humor. The joke to begin a speech, especially in a controversial or awkward situation, is a common example of enactment of the boost theory of relieve humor. The more tension relieve found, the more humor experienced. Freud also believed 
that humor was a means by which people could release their suppressed aggressive and sexual instinctive urges in a socially acceptable manner (Freud, 1960, as cited in Sen, 2012:76). For example, the students in biology labwere told they were about to help with biology experiment.The teacher said "The students would have to either hold rat, hold a vicious that could bite, or take a blood sample from a vicious rat". In each case, the rat they were actually handed was plastic (Shurcliif, 1968, as cited in Meyer, 2015:45).

Sure enough, the most humor was experienced by those thought to be in the more dangerous situations. The plastic rat provoked the most laughter and mirth in those that thought they would need to inject or hold a vicious rat, respectively. The more apprehension aroused by the stated planned task, the more humor participants experienced when the task turned out to be not the threat they had expected.

\section{The Incongruity Theory}

The Incongruity theory holds that humor results from a mental reaction to something unexpected, unusual, or odd in nonthreatening way when an accepted norm or pattern is violated (Meyer, 2015: 17). Appreciating humor requires the mental capacity to understand and categorize expected patterns and mild deviations from them, including an unexpected event or object, a physical or moral defect, an odd or disproportionate object, or an observable deviation from an implied standard.

An element of surprise is also a key ingredient in humor, but not essential. When an incongruity a violation of expected norms or mental reasoning patterns, suddenly and dramatically presents itself, a person seeks to resolve the incongruity.

For example, "How does an elephant hide in a cherry tree? It paints its toenails red". There is an incongruity in the fact that an elephant would climb in a cherry tree (an elephant would presumably squash the tree under its weight if it attempted to climb on it and moreover elephants are not arboreal creatures).

\section{The Superiority Theory}

According to Romero and Cruthirds (2006: 60), the Superiority theory postulates that people make themselves feel better at another's expense in order to achieve, or perceive that they have achieved, higher rank or status. It notes that people laugh outwardly or inwardly at others because they feel some sort of triumph over them or feel superior in some way to them. It also serves to explain the attraction of pleasant mirth responses as a common individual and social reaction to stupid or ignorant actions. 
Laughter follows descriptions of people acting in ignorant ways, as one commons on how "these people are too stupid to live." This violation or contradiction endemic to humor is held to have an edge to it, the violation indicates that superiority of those who perceive it and presumably would not engage in the violation themselves. A thriving source of enactments of superiority theory is accounts of people less than smart, or less than familiar with commonly accepted norms or knowledge.

The example:

The humor found as travel planners reported the following complaints from returning customers: "We want on holiday to Spain and had a problem with the taxi drivers as they were all Spanish." Humor here stems from a sense of superiority as we may chuckle and wonder, "How can people be so clueless?" There is a one-up and a one-down partly in all instances of humor, according to superiority approaches.

\section{The Functions of Humor}

According to Meyer (2000: 310), humor's enactment leads to basic functions of humor in communication. The functions can be viewed as falling along a continuum, starting with identification, then clarification, enforcement, and at the other extreme, differentiation. These are four basic rhetorical functions of humor in communication, drawing examples of each from a variety of rhetorical setting.

\section{Identification}

The appreciation of a sense of humor is an important part of growing and deeping relationships with people, as mutual uncertainty is reduced. These goals are sought when communicators try to release or reduce tensions through humor and make the hearer feel superior in the sense that they are brought up to a more equal relationship with the participant.

The example:

Ross Perot, during the first presidential debate in October 1992, responded to the other candidates' plans by saying that "if there are some good planes out there, I'm all ears."This is humor because the audience did not expect someone of his position to make such a remark, a remark that makes him seem like just another member of the audience expressing his honest thoughts. 


\section{Clarification}

Humorous lines often serve to express one's views creatively and memorably because they are presented incongruously or unexpectedly. Clarification shows humor in messages that serves to clarify social norms or perceptions, yet may also reduce tension and promote good feelings among communicators.

The example:

Ronald Reagan said he had no desire to make age an issue, during his debates with Walter Mondale in 1984, because of the "youth and inexperience" of his opponent. This is a way of saying that he's more superior than his opponent, but without the violence and serious note.

\section{Enforcement}

Humor can be a way to deliver criticism without being a 'critic.' It allows the participant to still relate with the hearer and avoid gaining negativism. Humor can teach and enforce social norms as well. These norms show how we are expected to behave. Therefore, a clarification of the social norms is required on this humor.

The example:

They can be seen clearly from observing children's responses. Children are yet to understand these norms, for example: "Why is Sunday school on Sunday? I thought it was supposed to be our day of rest." The humor lies in his incorrect view. This type of humor might also be some sort of correction of adult perspectives.

\section{Differentiation}

As a final function, communicators use differentiation quite often, constructing themselves with their opponents, their views with an opponent's views, their own social group with others, and so on. Differentiation is used to insulting and venomous as they are humor. Humor is invoked to make both alliances and distinctions.

The example:

An example of this might be a professor who says "Thank you for joining us today" to a student who walks in late to class. The sarcastic comment is funny to the rest of the class, but not so much for the one who are late. Also, there is no doubt in anyone's mind that the professor in sending a message to the late student not to be late again. 


\section{American Humor}

American humor's older genialities have come to be outweighed by the belligerent stridencies of recent times. The gentle readers of modern American humor,if there are any left, must beware of its vulgarity and violence in ethnic, political or sexual forms (Dudden, 1987:13). According to Jie (2016: 397), American humor might also be distinguished by its most common type of humor, for example, more slapstick and physical comedy. American humor tends to be more "obvious" and less oblique, and can sometimes be considered by other English speaking cultures to be over the top and ridiculous. Americans do not understand irony, it is not the foundation of American humor. When Americans use irony they tend to state that they were "only kidding". They feel the need to make a humor more obvious than Brits do.

Humor began to emerge in the United States soon after the American Revolution in written and spoken form, and delivery methods have continued to evolve since then. Literature appears before cartoons although newspaper cartoons in the modern sense began in the 1840 s. Radio and film came out roughly at the same time. Film is covered after radio because it led more directly to the television section. Stand-up comedy began to receive renewed attention in the 1970s which is the reason why it was placed directly after television.

\section{Related Previous Study}

In this research, the researcher also described the previous study. It was written by Mak (2008:34) entitled "Humor and Funny Stories: A Sociolinguistic Study of Newcomers' Socialization into Hong Kong Workplace". There were some similarities and differences between both of them. The similarities between Mak's research and this research were both of the researchers analyze the Humor in Sociolinguistic perspective that analysis the functions of humor. Both of the researchers also used library research for collecting the data of study and used qualitative research.

The differences between both of them are: (1) Mak analyzed newcomers' socialization into Hong Kong workplace, while the researcher analyzed American humor in comedy movie The Boss; (2) Mak analyzed the functions of humor and kinds of context are suitable for telling humor, while the researcher analyzed the language structures and functions of humor. 


\section{RESEARCH METHOD}

The research applied qualitative-descriptive method which will investigate the conversation in the movie and will be described in sentences form. Bodgan and Taylor (cited in Moleong, 1995:90) define qualitative method as a research which produces descriptive data in form of written words and/or spoken by people and performance which may be observed. It is description of something in words, not numbers.

In collecting the data, there are two techniques were applied including observation and noting technique, and library technique. Observation and noting technique will be used to obtain data transcription. Library technique is used to gather beneficial information from library sources such as journal articles, and books. The data were analyzed by identification and coding, classification, reduction and conclusion.

\section{FINDING}

After completing data analysis, there are some findings related to the problems such as the function of jokes according to Meyer's theory and joke usage according to setting and participant from Hymes. The findings are presented in the table below.

Table 1. Functions of Joke based on Meyer's theory and SP Holmes in The BossMovie

\begin{tabular}{|c|c|c|c|c|}
\hline No & Functions & Setting and Participant & Frequency & Total \\
\hline \multirow[t]{7}{*}{1} & Differentiation & 1. Informal-close relationship & 4 & 21 \\
\hline & - to insult & 2. Informal-distant relationship & 6 & \\
\hline & & 3. Formal-close relationship & 1 & \\
\hline & & 4. Formal-distant relationship & 3 & \\
\hline & - express anger & 1. Informal-close relationship & 1 & \\
\hline & & 2. Informal-distant relationship & 4 & \\
\hline & & 3. Formal-distant relationship & 2 & \\
\hline \multirow[t]{6}{*}{2} & Clarification & & & \\
\hline & relieve & 1. Informal-close relationship & 8 & 13 \\
\hline & tension & 2. Formal-distant relationship & 2 & \\
\hline & & 3. Formal-close relationship & 1 & \\
\hline & - $\quad$ To amuse others & 1. Formal-distant relationship & 1 & \\
\hline & & 2. Informal-close relationship & 1 & \\
\hline
\end{tabular}




\begin{tabular}{|c|c|c|c|c|}
\hline 3 & $\begin{array}{l}\text { Enforcement } \\
-\quad \text { to tease }\end{array}$ & $\begin{array}{l}\text { 1. Informal-close relationship } \\
\text { 2. Informal-distant relationship } \\
\text { 3. Formal-close relationship } \\
\text { 4. Formal-distant relationship }\end{array}$ & $\begin{array}{c}10 \\
5 \\
1 \\
2\end{array}$ & 18 \\
\hline 4 & $\begin{array}{l}\text { Identification: } \\
-\quad \text { to relieve tension }\end{array}$ & $\begin{array}{ll}\text { 1. } & \text { Informal-close relationship } \\
\text { 2. Informal-distant relationship } \\
\text { 3. } & \text { Formal-distant relationship } \\
\text { 4. } & \text { Formal-close relationship }\end{array}$ & $\begin{array}{l}9 \\
6 \\
4 \\
3\end{array}$ & 27 \\
\hline & - to get attention & $\begin{array}{l}\text { 1. Informal-close relationship } \\
\text { 2. Informal-distant relationship }\end{array}$ & $\begin{array}{l}3 \\
2\end{array}$ & \\
\hline & Jokes & & & \\
\hline
\end{tabular}

There aresix functions from all 79 jokes found in The Boss. Specifically, each function may explain detail purposes when the jokes were expressed by the participants. The distinction was also presented in which the participants express them in different setting and with different participants. Identification is as the most frequent function occurs in the movie with specific purpose of relieving tension of the participants.

\section{DISCUSSION}

In the findings section, the researcher presented the result of the research briefly. Meanwhile in this section, the researcher presented depth explanations of these result. This section presents the discussion of the functions of humor deeply.

Based on the result, researcher found some humors that were used in The Bossmovie. According to Attardo (1994:4), humor is all encompassing category, covering any event or object that elicits laughter, amuses, or it is felt to be funny. The people use humor as one of way to communicate each other.Therefore, expressing humor is expressing the participant intention which covers different function.

According to Meyer (2000: 310), humor's enactment leads to basic functions of humor in communication. The functions can be viewed as falling into identification (to relieving himself /other), then clarification (to reducing tensions by using incongruity strategy or unexpected utterance), enforcement (to teasing someone), and at the other extreme, differentiation (to insulting someone). Supported by Meyer analysis of joke, the findings presented in the article tend to describe the jokes used by white Americans and it is overviewed by the Sociolinguistics perspective. 
Based on the result of finding, the dominant function of humor in this movie is differentiation. It occurred 22 times. The utterances such as fuck you; you are bitch; you get a big plate of bullshit; and you seem fucking crazy to me frequently appear in the whole story of The Boss movie. The differentiation is the function of humor to insult someone. The aims of this function were to attack others or to show their anger. Therefore, the utterances that would be used by them would be slapstick. According to Jie (2016:397), American humor might also be distinguished by its most common type of humor, for example, more slapstick and physical comedy. This function also has relationship with the theory of humor origin by Meyer (2000:12), it was superiority theory. According to Romero and Cruthirds (2006:60), the Superiority theory postulates that people make themselves feel better at another's expense in order to achieve, or perceive that they have achieved, higher rank or status.

Used in different setting and participant, there are some cases which have to be concerned correspond to American jokes function to insult someone and to express anger. It is not surprising when there are some taboo words and impolite expression used when speakers speak in a close relationship. It also happens as the use of jokes functions to embrace all members in the conversation. But it is quite surprising that jokes function to insult and to express anger directed to someone with a distant relationship. As we know that there are some considerations when speaking to someone with distant relationship. We probably think that it is impolite or may be offense the person. However, it can be assumed that insulting and expressing anger jokes occur because the speaker was disturbed by something which triggers the emotion to express. The jokes may sound funny to others but it may sound humiliating to the interlocutors. In the formal-distant relationship as presented in the movie, the speaker and the hearer did not know each other but there was something which disturb the speakers that lead to a dispute. Therefore, the jokes functioned to insult and to express anger occur with the insertion of taboo words even though the relationship was distant and it happened in the formal situation (classroom). For example, You get a big plate of bullshit was expressed by inserting a taboo word bullshit because the first speaker was angry with the second speaker.

The next function of humor is clarification. Clarification is the function of humor to reduce tensions by using incongruity or unexpected utterances in humorous line or short anecdotes. The unexpected utterances that they said were included as types of vulgar utterances, but it created humor and made the people laugh, especially for Americans. This statement was supported by Duden's theory (1987:34). The gentle readers of modern American humor must beware of its vulgarity and violence 
in ethnic, political, or sexual forms (Duden, 1987:13). The theory supported the data found in The Boss that some vulgar words were used in the jokes including swearing words and sensitive parts of body. Clarification correspondsto the incongruity theory of humor originally by Meyer (2000:76). The Incongruity theory holds that humor results from a mental reaction to something unexpected, unusual, or odd in nonthreatening way when an accepted norm or pattern is violated (Meyer, 2015:17).

There are two particular functions in clarification including to release others tension and to amuse others. Both functions tend to the unexpected utterances said by the speakers. In releasing others tension, the first speaker tended to affect other speakers that he/she support others by praising the interlocutor and supporting with statements.In example All right, here's a little joke for everybody. What do golfers do on their day off?Putter around.is humorous lines which relieve tension among communicators. It was also said unexpectedly in the punchline that cause laughter. Another example is in Well congratulations and you're welcome !.you know, I had it rejuvenated in 2010. They call it a Vaguvenation!when the joke user deflected something about her vagina as mentioned by the first speaker. The humorous lines were stated in incongruity which will cause others to laugh listening to the unexpected utterances. Therefore, all of the jokes require a clarification of social norms due to the mild violation.

In amusing others, the speaker employed the expression of lies directed to the interlocutor. As found in the movie, the speaker said unpleasant thing but then it was clarified into a praise directed to the second speaker. As in You seem fucking crezy to me which was changed into Cute as a daisy to me. This kind of deflection triggered laughter to people who listen because what is expected changed into something unexpectedly funny.

The third function is enforcement. Enforcement function often involves children who violate norms that produce a mirthful experience. Children often said something unexpectedly in the end but it finally become suggestion to adults. There are some norms that have to be learnt because they have different perspective from adults. We can say that children perspective in their utterances may engender humorous situation. However, what the said might be the norms enforcement which clarifies adults restricted cultural knowledge in behaving and using language. In the movie jokes with teasing function were expressed to deliver a strong content of messages, almost forcing, in mild violation by replacing some cruel expression to a milder expression. The joke found in the movie which employ this function as in: 
It doesn't suit you or your skin or your face. That sweater is the equivalent of a sandwich board that just says "I give up" and then in the back it says "I never started trying". It somewhat looks like you have sewn together two very long, sad tobe socks and then filled each end with wet sand any rock.

The lines presented some flusters that actually refer to the discussion of an old sweater. Some words and expressions intentionally were selected to avoid a harsh violation which may offend the interlocutor. In teasing, participants tend to insult by indicating a suggestion said indirectly to the interlocutor but rather to say it to other participants or say about something which has similar intention as stated in the previous example. People also said slapstick utterances to teas as well as insult someone. It means that, this function also has relationship with the superiority theory. The people would feel a joy at feeling superior to others. The jokes were less occurred in the formal situation to distant relationship. The data seem to be a common thing in which people usually speak in manner to people with distant relationship and in the formal situation. Therefore, jokes of teasing in this situation particularly derived from the situation which indicate the disagreement toward something. For example, That cat probably killed himself because his name was "Spaghetti" presents a disagreement which expressed against the fact that the speaker thought it was ridiculous to name a cat Spaghetti. It can be interpreted as That is so ridiculous or That is a stupid thing if the utterance is replaced by other utterances.

Furthermore, for example, You are a beautiful giant and That is so supportive, Ron! are two forms of the expression of jokes which function to insult and to tease. Insulting is directive expressed through the utterances which shows the expression of affront and humiliation. As in the example, the first speaker insulted the second speaker, set in the classroom, as she looked like a giant. On the other hand, the second utterance indicated teasing because supportive might be mean tricky because the second speaker was a tricky businessman or a criminal. Therefore, the explanation above clarifies the function of joke by Meyer in which he emphasized humor to correct or suggest other misbehavior. However, teasing may be aims to deliver opinion correspond to disagreement toward something.

Frequently the differentiation and enforcement are not pleasant types of humor for those subjected to it. It will divisive the relationship between one group to others because it requires a clarification of social norms. On the other hand, the differentiation and enforcement can unify a group participating in their humor. It can give the strength for one group to against another by laughter. Therefore, when Meyer (2000:56) stated that enforcement and differentiation (as divider) tend to divides one 
set of communicators, it may be true. However, in another one set of communicators the function as divider can be incorrect when sharing the similar sense of humiliating others may strengthen the relationship in that one set. It can be said that in one situation there is a possibility that some sets of communicators are involved to a similar topic but do not share the same sense in the same set. Thus, the occurrence of jokes may classify which group they belong to.

The last function is identification, they used humor to relieving himself/others which may embrace all communicators as one set who shared common feeling. It employs relief and superiority theory in which the jokes aim to relieve tension of speakers as well as make the speaker inferior to others just to indicate that one belongs to the group. For example, It was white collar crime was expressed by a little girl who did not really know about white collar crime. She stated because she had her prior knowledge which was shared by an adult. The little girl's joke indicated a support to Rachel who argued about something and having a stress feeling. This joke relieved Rachel's tension and indicated that they were in the same side. As Relieve theory stated that humor results from reducing stress or tension, often suddenly, and allows release of nervous energy. The type of this function can be used in such ways to bring both of the communicators closer. The function of humor as clarification and identification showed the violation as a humorous exception to the normal, reassuring, relaxing state that is expected. It showed that one can laugh at such situations made the participants or hearers seem relaxed and more in control.

The function may also socially be discriminated by the social factors such as setting and participant. The setting in this research refers to formal and informal setting and the participants are distinguished by the distance i.e. close and distant relationship. The application of jokes in daily communication in the movie presented some novel things according to the place and the people who involved.

By the function analysis, it was known that jokes are uttered in the informal situation such as in the residence (at home and top of building) and to second speaker who has close relationship to the first participant. It indicates that the appropriate timing of stating jokes is almost always in the informal setting and to second participant with close relationship. In this kind of setting and participant, the language used by participants are casual which presents the solidarity. Most of jokes also contain taboo words with total frequency 24 taboo words. It can be assumed that jokes presented in The Bossmeet the characteristic of American humor which contain vulgarity.

Some jokes were also expressed in the formal setting such as in the classroom to distant participant. Some jokes like cute as daisy to me and I like Sarah whatever 
either onewere uttered in the similar setting and participantwith taboo words used. But frankly, in this setting, jokes were also stated by inserting taboo words such as you suck at this, you get a big plate of bullshit, fuckin and ass. It happened due to the function of jokes i.e. to express anger. The uses of taboo words are actually stress the information which attracts attention from interlocutors.

\section{CONCLUSION}

Humor is part the social communication among language participants. Expressing jokes is one of the most essential things to attract other people attention. They function as icebreaker in different setting and to different participants. As Meyer (2000:23) states that there are four functions of humor. Those four functions occur particularly with certain purposes.

As a result of the analysis, four functions from Meyer's theory (identification, clarification, enforcement and differentiation) occur with specific purposes. Identification particularly functions to relievetension and to get attention.Clarification particularly functions to relieve tension through humorous lines and to amuse others. Enforcement particularly functions to tease someone. Differentiation particularly functions to insult someone and to express anger. According to the findings and analysis of American jokes in The Boss, it can be stated that Meyer only explain the four general functions of humor without break it down into specific function socially. By discriminating and describing the function in a particular way, it may assist language users to understand several jokes to be employed in different setting and participants.

The use of jokes which distinguished by setting and participant (Holmes, 2013:45) indicates that jokes are expressed in both setting i.e. formal and informal setting. They are also uttered to both participants relationship, distant and close. The analysis shows that most jokes occur in informal-close relationship which functions to tease someone. The characteristic of American comedy which contain slapstick and vulgarity (taboo words) was also found in the movie particularly in informalclose relationship. There are 24 taboo words were found in the expression of humor both in formal and informal setting as well to close and distant relationship of the participants. Finally, the classification of humor use in The Boss movie attempts to describe and present the usage of humor based on different setting and participant with different functions. Theoretically it may be beneficial for future research in investigating humor used in society with other social factors. Practically, it may be 
useful for people to learn about the proper way in using American jokes to different setting with different participants.

\section{REFERENCES}

Attardo, S. (1994). Linguistic theories of humor. New York, NY: Mouton de Gruyter. Dudden, A. P. (1987). American humor. New York: Oxford University Press.

Holmes, J. (2013). An introduction to sociolinguistics ( $4^{\text {th }}$ ed.). New York: Routledge. $\mathrm{Hu}$, S. (2012). An analysis of humor in the big bang theory from pragmatic perspectives. Theory and practice in language studies, 2(6), 1185-1190.

Jie, Z. (2016). James Thurber's humor represents typical American humor. Sino-US English Teaching, 5(13), 395-400. doi:10.17265/1539-8072/2016.05.009.

Mak, B. (2008). Humor and funny stories: A sociolinguistic study of newcomers' socialization into Hong Kong workplaces. The university of Hong Kong, Hong Kong.

Meyer, C. F. (2009). Introducing Englishlinguistics. Cambridge: Cambridge University Press.

Meyer, J. C. (2000). Humor as a double-edged sword: Four functions of humor in communication. Communication Theory, 10, 310-311.

Meyer, J. C.. (2015). Understanding humor through communication: why be funny anyway?. [e-book]. RetrievedOctober 10, 2016, from http://books.google.co.id/books?Understanding+Humor+through+Communi cation++Why+Be+Funny,+Anyway+++John+C.+Meyer.

Moleong. (1995). Metode Penelitian Kualitatif. Jakarta: Pustaka Setia

Romero, E.J. \&Cruthirds, K.W. (2006). The use of humour in the wokrplace. Academy of management perspectives, 20(2), 58-69.

Seitz, M. Z. (2016), April 8. The BossMovie Review \& Film Summary 2016. Retrieved October 20, 2016, from http://www.rogerebert.com/reviews/the-boss-2016.

Sen, A. (2012). Humor analysis and qualitative research. Social Research Update, 63,1360-7898. 
APPENDIX

\section{Identification}

a. To relief of tensions

\begin{tabular}{|c|l|l|l|l|}
\hline No & \multicolumn{1}{|c|}{ Utterance } & \multicolumn{1}{|c|}{$\begin{array}{c}\text { Humor } \\
\text { Theory }\end{array}$} & \multicolumn{1}{|c|}{ Setting } & \multicolumn{1}{|c|}{ Participant } \\
\hline 1 & $\begin{array}{l}\text { I was hoping you would say } \\
\text { that because I love rejection. }\end{array}$ & Relief & $\begin{array}{l}\text { In the office } \\
\text { (Informal) }\end{array}$ & $\begin{array}{l}\text { A distant } \\
\text { relationship } \\
\text { (2 }\end{array}$ \\
\hline 2 & Cool.. & Relief & $\begin{array}{l}\text { In the office } \\
\text { (Informal) }\end{array}$ & $\begin{array}{l}\text { A distant } \\
\text { relationship } \\
\text { (2 }{ }^{\text {nd }} \text { speaker) }\end{array}$ \\
\hline 3 & Jesus christ! & Relief & $\begin{array}{l}\text { In the lift of } \\
\text { apartment } \\
\text { (Informal) }\end{array}$ & $\begin{array}{l}\text { A distant } \\
\text { relationship }\left(2^{\text {nd }}\right. \\
\text { speaker) }\end{array}$ \\
\hline 4 & You're tempted... & Relief & $\begin{array}{l}\text { On the road } \\
\text { (Informal) }\end{array}$ & $\begin{array}{l}\text { A distant } \\
\text { relationship }\left(2^{\text {nd }}\right. \\
\text { speaker) }\end{array}$ \\
\hline 5 & Fucking Tito! & Relief & $\begin{array}{l}\text { At home } \\
\text { (Informal) }\end{array}$ & $\begin{array}{l}\text { A close } \\
\text { relationship }\left(3^{\text {rd }}\right. \\
\text { speaker) }\end{array}$ \\
\hline 6 & She is a nightmare & Relief & $\begin{array}{l}\text { In the office } \\
\text { (Informal) }\end{array}$ & $\begin{array}{l}\text { A distant } \\
\text { relationship }\left(3^{\text {rd }}\right. \\
\text { speaker) }\end{array}$ \\
\hline 7 & They are not gonna bite you & Relief & $\begin{array}{l}\text { In bakery } \\
\text { (Informal) }\end{array}$ & $\begin{array}{l}\text { A distant } \\
\text { relationship }\left(2^{\text {nd }}\right. \\
\text { speaker) }\end{array}$ \\
\hline
\end{tabular}

\section{b. To get attention}

\begin{tabular}{|c|l|l|l|l|}
\hline No & \multicolumn{1}{|c|}{ Utterance } & \multicolumn{1}{|c|}{$\begin{array}{c}\text { Humor } \\
\text { Theory }\end{array}$} & \multicolumn{1}{|c|}{ Setting } & \multicolumn{1}{|c|}{ Participant } \\
\hline 1 & $\begin{array}{l}\text { I am a ginger, but I am a } \\
\text { natural red head }\end{array}$ & Relief & $\begin{array}{l}\text { Tennis court } \\
\text { (Informal) }\end{array}$ & $\begin{array}{l}\text { A close } \\
\text { relationship }\left(2^{\text {nd }}\right. \\
\text { speaker) }\end{array}$ \\
\hline 2 & White collar crime & Relief & $\begin{array}{l}\text { In front of home } \\
\text { (Informal) }\end{array}$ & $\begin{array}{l}\text { A distant } \\
\text { relationship } \\
\text { (2) } \text { speaker) }\end{array}$ \\
\hline 3 & Fuck you! & Relief & $\begin{array}{l}\text { Orphanage's } \\
\text { yard } \\
\text { (Informal) }\end{array}$ & $\begin{array}{l}\text { A distant } \\
\text { relationship } \\
\text { (2nd } \text { speaker) }\end{array}$ \\
\hline 4 & $\begin{array}{l}\text { Remember girls, when the } \\
\text { houses are nice, we double the } \\
\text { price }\end{array}$ & Incongruity & $\begin{array}{l}\text { On the road } \\
\text { (Informal) }\end{array}$ & $\begin{array}{l}\text { A close } \\
\text { relationship }\left(2^{\text {nd }}\right. \\
\text { speaker) }\end{array}$ \\
\hline 5 & $\begin{array}{l}\text { Vaguvenation } \\
\text { A close } \\
\text { relationship }\left(2^{\text {nd }}\right. \\
\text { speaker) }\end{array}$ \\
\hline
\end{tabular}




\section{Clarification}

\section{a. To relief of tensions}

\begin{tabular}{|c|c|c|c|c|}
\hline No & Utterance & $\begin{array}{l}\text { Humor } \\
\text { Theory }\end{array}$ & Setting & Participant \\
\hline 1 & $\begin{array}{l}\text { It is like a soft silk coin purse. } \\
\text { I can barely urinate }\end{array}$ & Incongruity & $\begin{array}{l}\text { At home } \\
\text { (Informal) }\end{array}$ & $\begin{array}{l}\text { A close } \\
\text { relationship }\left(2^{\text {nd }}\right. \\
\text { speaker })\end{array}$ \\
\hline 2 & Namaste! & Relief & $\begin{array}{l}\text { At home } \\
\text { (Informal) }\end{array}$ & $\begin{array}{l}\text { A close } \\
\text { relationship }\left(2^{\text {nd }}\right. \\
\text { speaker })\end{array}$ \\
\hline 3 & Putter around & Incongruity & $\begin{array}{l}\text { In the restaurant } \\
\text { (Informal) }\end{array}$ & $\begin{array}{l}\text { A close } \\
\text { relationship }\left(2^{\text {nd }}\right. \\
\text { speaker })\end{array}$ \\
\hline 4 & $\begin{array}{l}\text { I like sarah, whatever either } \\
\text { one }\end{array}$ & Relief & $\begin{array}{l}\text { In the class } \\
\text { (Formal) }\end{array}$ & $\begin{array}{l}\text { A distant } \\
\text { relationship }\left(2^{\text {nd }}\right. \\
\text { speaker })\end{array}$ \\
\hline 5 & Super necessary & Relief & $\begin{array}{l}\text { In the class } \\
\text { (Formal) }\end{array}$ & $\begin{array}{l}\text { A close } \\
\text { relationship }\left(2^{\text {nd }}\right. \\
\text { speaker })\end{array}$ \\
\hline 6 & I may have switchhed them & Incongruity & $\begin{array}{l}\text { School's yard } \\
\text { (Informal) }\end{array}$ & $\begin{array}{l}\text { A close } \\
\text { relationship }\left(2^{\text {nd }}\right. \\
\text { speaker })\end{array}$ \\
\hline 7 & You are sucking his dick & Incongruity & $\begin{array}{l}\text { In the apartment } \\
\text { (Informal) }\end{array}$ & $\begin{array}{l}\text { A close } \\
\text { relationship }\left(2^{\text {nd }}\right. \\
\text { speaker })\end{array}$ \\
\hline 8 & I will suck your dick & Incongruity & $\begin{array}{l}\text { In the apartment } \\
\text { (Informal) }\end{array}$ & $\begin{array}{l}\text { A close } \\
\text { relationship }\left(2^{\text {nd }}\right. \\
\text { speaker })\end{array}$ \\
\hline 9 & $\begin{array}{l}\text { You know why we like } \\
\text { vaginas better than your } \\
\text { mouth, because they do not } \\
\text { have teeth and they do not talk }\end{array}$ & Incongruity & $\begin{array}{l}\text { At home } \\
\text { (Informal) }\end{array}$ & $\begin{array}{l}\text { A close } \\
\text { relationship }\left(2^{\text {nd }}\right. \\
\text { speaker })\end{array}$ \\
\hline 10 & The cat & Incongruity & $\begin{array}{l}\text { In the class } \\
\text { (Formal) }\end{array}$ & $\begin{array}{l}\text { A distant } \\
\text { relationship }\left(2^{\text {nd }}\right. \\
\text { speaker })\end{array}$ \\
\hline 11 & $\begin{array}{l}\text { I am self -tenning and my legs } \\
\text { are still wet }\end{array}$ & Incongruity & $\begin{array}{l}\text { At home } \\
\text { (Informal) }\end{array}$ & $\begin{array}{l}\text { A close } \\
\text { relationship }\left(2^{\text {nd }}\right. \\
\text { speaker })\end{array}$ \\
\hline
\end{tabular}


b. To amuse someone

\begin{tabular}{|c|l|l|l|l|}
\hline No & \multicolumn{1}{|c|}{ Utterance } & \multicolumn{1}{|c|}{$\begin{array}{c}\text { Humor } \\
\text { Theory }\end{array}$} & \multicolumn{1}{|c|}{ Setting } & \multicolumn{1}{|c|}{ Participant } \\
\hline 1 & Cute as a daisy to me & Relief & $\begin{array}{l}\text { In the class } \\
\text { (Formal) }\end{array}$ & $\begin{array}{l}\text { A distant } \\
\text { relationship }\left(2^{\text {nd }}\right. \\
\text { speaker) }\end{array}$ \\
\hline 2 & $\begin{array}{l}\text { Always gotta tretch your } \\
\text { boobs when you are nervous }\end{array}$ & Incongruity & $\begin{array}{l}\text { At home } \\
\text { (Informal) }\end{array}$ & $\begin{array}{l}\text { A close } \\
\text { relationship }\left(2^{\text {nd }}\right. \\
\text { speaker) }\end{array}$ \\
\hline
\end{tabular}

\section{Enforcement}

\section{a. To tease someone}

\begin{tabular}{|c|c|c|c|c|}
\hline No & Utterance & $\begin{array}{l}\text { Humor } \\
\text { Theory }\end{array}$ & Setting & Participant \\
\hline 1 & $\begin{array}{l}\text { Somebody gets very scrabby when } \\
\text { she is hungry }\end{array}$ & Superiority & $\begin{array}{l}\text { In the } \\
\text { apartment } \\
\text { (Informal) }\end{array}$ & $\begin{array}{l}\text { A distant } \\
\text { relationship }\left(2^{\text {nd }}\right. \\
\text { speaker })\end{array}$ \\
\hline 2 & Who is on my baseball? & Superiority & $\begin{array}{l}\text { In the } \\
\text { apartment } \\
\text { (Informal) }\end{array}$ & $\begin{array}{l}\text { A close } \\
\text { relationship }\left(2^{\text {nd }}\right. \\
\text { speaker })\end{array}$ \\
\hline 3 & Do you work at the excuse factory? & Superiority & $\begin{array}{l}\text { In the office } \\
\text { (Informal) }\end{array}$ & $\begin{array}{l}\text { A distant } \\
\text { relationship }\left(2^{\text {nd }}\right. \\
\text { speaker })\end{array}$ \\
\hline 4 & So far you suck at this & Superiority & $\begin{array}{l}\text { In the class } \\
\text { (Formal) }\end{array}$ & $\begin{array}{l}\text { A close } \\
\text { relationship }\left(2^{\text {nd }}\right. \\
\text { speaker })\end{array}$ \\
\hline 5 & $\begin{array}{l}\text { I think you should toss him a pity } \\
\text { date }\end{array}$ & Superiority & $\begin{array}{l}\text { In the office } \\
\text { (Informal) }\end{array}$ & $\begin{array}{l}\text { A close } \\
\text { relationship }\left(2^{\text {nd }}\right. \\
\text { speaker })\end{array}$ \\
\hline 6 & $\begin{array}{l}\text { You are dressed like you grocery } \\
\text { shop at a CVS }\end{array}$ & Superiority & $\begin{array}{l}\text { At home } \\
\text { (Informal) }\end{array}$ & $\begin{array}{l}\text { A close } \\
\text { relationship }\left(2^{\text {nd }}\right. \\
\text { speaker })\end{array}$ \\
\hline 7 & $\begin{array}{l}\text { It just looks like two bsset hounds } \\
\text { may heve cried themselves to death } \\
\text { in your sweater }\end{array}$ & Superiority & $\begin{array}{l}\text { At home } \\
\text { (Informal) }\end{array}$ & $\begin{array}{l}\text { A close } \\
\text { relationship ( } 2^{\text {nd }} \\
\text { speaker })\end{array}$ \\
\hline 8 & Are you still nursing rachel? & Superiority & $\begin{array}{l}\text { At home } \\
\text { (Informal) }\end{array}$ & $\begin{array}{l}\text { A close } \\
\text { relationship }\left(2^{\text {nd }}\right. \\
\text { speaker })\end{array}$ \\
\hline 9 & It is like horses, horses & Superiority & $\begin{array}{l}\text { At home } \\
\text { (Informal) }\end{array}$ & $\begin{array}{l}\text { A close } \\
\text { relationship }\left(2^{\text {nd }}\right. \\
\text { speaker })\end{array}$ \\
\hline 10 & $\begin{array}{l}\text { I will send somebody to walgreens } \\
\text { to get you something nice }\end{array}$ & Incongruity & $\begin{array}{l}\text { At the cafe } \\
\text { (Informal) }\end{array}$ & $\begin{array}{l}\text { A close } \\
\text { relationship }\left(2^{\text {nd }}\right. \\
\text { speaker })\end{array}$ \\
\hline 11 & Should I go? & Incongruity & $\begin{array}{l}\text { At home } \\
\text { (Informal) }\end{array}$ & $\begin{array}{l}\text { A distant } \\
\text { relationship }\left(2^{\text {nd }}\right. \\
\text { speaker })\end{array}$ \\
\hline
\end{tabular}




\begin{tabular}{|c|c|c|c|c|}
\hline 12 & $\begin{array}{l}\text { It is a nice idea michelle, but it is } \\
\text { also a crazy one }\end{array}$ & Superiority & $\begin{array}{l}\text { At home } \\
\text { (Informal) }\end{array}$ & $\begin{array}{l}\text { A distant } \\
\text { relationship }\left(2^{\text {nd }}\right. \\
\text { speaker })\end{array}$ \\
\hline 13 & $\begin{array}{l}\text { That cat probably killed himself } \\
\text { because his name was "Spaghetti" }\end{array}$ & Superiority & $\begin{array}{l}\text { In the class } \\
\text { (formal) }\end{array}$ & $\begin{array}{l}\text { A distant } \\
\text { relationship }\left(2^{\text {nd }}\right. \\
\text { speaker })\end{array}$ \\
\hline 14 & $\begin{array}{l}\text { If your breasts could speak right } \\
\text { now, I think they would be saying } \\
\text { "Claire, please do not zip me upin } \\
\text { your jeans" }\end{array}$ & Superiority & $\begin{array}{l}\text { At home } \\
\text { (Informal) }\end{array}$ & $\begin{array}{l}\text { A close } \\
\text { relationship }\left(2^{\text {nd }}\right. \\
\text { speaker })\end{array}$ \\
\hline 15 & $\begin{array}{l}\text { That sweater is the equivalent of a } \\
\text { sandwich board that just says "I } \\
\text { give up" and then in the back it says } \\
\text { "I never started trying". }\end{array}$ & Superiority & $\begin{array}{l}\text { At home } \\
\text { (Informal) }\end{array}$ & $\begin{array}{l}\text { A close } \\
\text { relationship }\left(2^{\text {nd }}\right. \\
\text { speaker })\end{array}$ \\
\hline 16 & $\begin{array}{l}\text { It somewhat looks like you have } \\
\text { sewn together two very long, sad } \\
\text { tobe socks and then filled each end } \\
\text { with wet sand any rock }\end{array}$ & Superiority & $\begin{array}{l}\text { At home } \\
\text { (Informal) }\end{array}$ & $\begin{array}{l}\text { A close } \\
\text { relationship }\left(2^{\text {nd }}\right. \\
\text { speaker })\end{array}$ \\
\hline 17 & Oh, rejecting mike & Superiority & $\begin{array}{l}\text { In the office } \\
\text { (Informal) }\end{array}$ & $\begin{array}{l}\text { A distant } \\
\text { relationship }\left(2^{\text {nd }}\right. \\
\text { speaker })\end{array}$ \\
\hline 18 & You are beautiful giant & Superiority & $\begin{array}{l}\text { In the class } \\
\text { (Formal) }\end{array}$ & $\begin{array}{l}\text { A close } \\
\text { relationship }\left(2^{\text {nd }}\right. \\
\text { speaker })\end{array}$ \\
\hline
\end{tabular}

\section{Differentiation}

\section{a. To Insult Someone}

\begin{tabular}{|c|l|l|l|l|}
\hline No & \multicolumn{1}{|c|}{ Utterance } & \multicolumn{1}{|c|}{$\begin{array}{c}\text { Humor } \\
\text { Theory }\end{array}$} & \multicolumn{1}{|c|}{ Setting } & \multicolumn{1}{|c|}{ Participant } \\
\hline 1 & Was that through intercourse? & Superiority & $\begin{array}{l}\text { In the } \\
\text { apartment } \\
\text { (Informal) }\end{array}$ & $\begin{array}{l}\text { A close } \\
\text { relationship }\left(2^{\text {nd }}\right. \\
\text { speaker) }\end{array}$ \\
\hline 2 & $\begin{array}{l}\text { She is a business woman, a } \\
\text { visionary, a leader, a natural born } \\
\text { cocksucker, a motherfucker, an } \\
\text { ass-wipe, a shit stain, and sewer rat, } \\
\text { fuck face professional. }\end{array}$ & Incongruity & $\begin{array}{l}\text { In TV } \\
\text { program } \\
\text { (Formal) }\end{array}$ & $\begin{array}{l}\text { A close } \\
\text { relationship (3 } \\
\text { speaker) }\end{array}$ \\
\hline 3 & Ronald & Superiority & $\begin{array}{l}\text { On the top } \\
\text { of building } \\
\text { (Informal) }\end{array}$ & $\begin{array}{l}\text { A distant } \\
\text { relationship (3 } \\
\text { speaker) }\end{array}$ \\
\hline
\end{tabular}




\begin{tabular}{|c|c|c|c|c|}
\hline 4 & Jersey & Superiority & $\begin{array}{l}\text { On the top } \\
\text { of building } \\
\text { (Informal) }\end{array}$ & $\begin{array}{l}\text { A distant } \\
\text { relationship } \\
\left(3^{\text {rd }} \text { speaker }\right)\end{array}$ \\
\hline 5 & That is so supportive, Ron! & Incongruity & $\begin{array}{l}\text { In the office } \\
\text { (Informal) }\end{array}$ & $\begin{array}{l}\text { A distant } \\
\text { relationship } \\
\left(2^{\text {nd }} \text { speaker }\right)\end{array}$ \\
\hline 6 & She thought a town car was coming & Superiority & $\begin{array}{l}\text { On the road } \\
\text { (Informal) }\end{array}$ & $\begin{array}{l}\text { A distant } \\
\text { relationship } \\
\left(2^{\text {nd }} \text { speaker }\right)\end{array}$ \\
\hline 7 & $\begin{array}{l}\text { Your pelvic region is the color of } \\
\text { curry }\end{array}$ & Superiority & $\begin{array}{l}\text { At home } \\
\text { (Informal) }\end{array}$ & $\begin{array}{l}\text { A close } \\
\text { relationship }\left(2^{\text {nd }}\right. \\
\text { speaker })\end{array}$ \\
\hline 8 & Jailbird & Superiority & $\begin{array}{l}\text { In the class } \\
\text { (Formal) }\end{array}$ & $\begin{array}{l}\text { A distant } \\
\text { relationship } \\
\left(2^{\text {nd }} \text { speaker }\right)\end{array}$ \\
\hline 9 & Lots of hand, oh helen..tooot!! & Superiority & $\begin{array}{l}\text { In the class } \\
\text { (Formal) }\end{array}$ & $\begin{array}{l}\text { A distant } \\
\text { relationship } \\
\left(2^{\text {nd }} \text { speaker }\right)\end{array}$ \\
\hline 10 & $\begin{array}{l}\text { Next week, I am thinking may be } \\
\text { they will arrange marriages }\end{array}$ & Superiority & $\begin{array}{l}\text { At home } \\
\text { (Informal) }\end{array}$ & $\begin{array}{l}\text { A close } \\
\text { relationship }\left(2^{\text {nd }}\right. \\
\text { speaker })\end{array}$ \\
\hline 11 & Who is that beast? & Superiority & $\begin{array}{l}\text { On the yard } \\
\text { (Informal) }\end{array}$ & $\begin{array}{l}\text { A distant } \\
\text { relationship } \\
\left(3^{\text {rd }} \text { speaker }\right)\end{array}$ \\
\hline 12 & You get a big plate of bullshit & Incongruity & $\begin{array}{l}\text { In the class } \\
\text { (Formal) }\end{array}$ & $\begin{array}{l}\text { A distant } \\
\text { relationship } \\
\left(2^{\text {nd }} \text { speaker }\right)\end{array}$ \\
\hline 13 & Buy my brownies or I will kill you & Superiority & $\begin{array}{l}\text { On the road } \\
\text { (Informal) }\end{array}$ & $\begin{array}{l}\text { A distant } \\
\text { relationship } \\
\left(3^{\text {rd }} \text { speaker }\right)\end{array}$ \\
\hline 14 & Do not tell your mom! & $\begin{array}{l}\text { To relief } \\
\text { themselves }\end{array}$ & $\begin{array}{l}\text { On the road } \\
\text { (Informal) }\end{array}$ & $\begin{array}{l}\text { A close } \\
\text { relationship }\left(2^{\text {nd }}\right. \\
\text { speaker })\end{array}$ \\
\hline
\end{tabular}

\section{b. To express anger}

\begin{tabular}{|c|l|l|l|l|}
\hline No & \multicolumn{1}{|c|}{ Utterance } & \multicolumn{1}{|c|}{$\begin{array}{c}\text { Humor } \\
\text { theory }\end{array}$} & Setting & Participant \\
\hline 1 & Fuck off! & Relief & $\begin{array}{l}\text { In the office } \\
\text { (Informal) }\end{array}$ & $\begin{array}{l}\text { A distant } \\
\text { relationship } \\
\text { (3 } 3^{\text {rd }} \text { speaker) }\end{array}$ \\
\hline 2 & You are bitch & Incongruity & $\begin{array}{l}\text { In the office } \\
\text { (Informal) }\end{array}$ & $\begin{array}{l}\text { A distant } \\
\text { relationship } \\
\text { (2) } \text { speaker })\end{array}$ \\
\hline 3 & Stupid ginger! & $\begin{array}{l}\text { On the road } \\
\text { (Informan) }\end{array}$ & $\begin{array}{l}\text { A close } \\
\text { relationship } \\
\left(2^{\text {nd }} \text { speaker }\right)\end{array}$ \\
\hline
\end{tabular}




\begin{tabular}{|c|l|l|l|l|}
\hline 4 & Go to the hell, Michelle! & Relief & $\begin{array}{l}\text { In the } \\
\text { restaurant } \\
\text { (Informal })\end{array}$ & $\begin{array}{l}\text { A distant } \\
\text { relationship } \\
\left(2^{\text {nd }} \text { speaker }\right)\end{array}$ \\
\hline 5 & $\begin{array}{l}\text { When I get to the hell, I will tell } \\
\text { pam that you said hello, because } \\
\text { she is probably down there fuckigit } \\
\text { guys }\end{array}$ & Incongruity & $\begin{array}{l}\text { In the } \\
\text { restaurant } \\
\text { (Informal })\end{array}$ & $\begin{array}{l}\text { A distant } \\
\text { relationship } \\
\left(2^{\text {nd }} \text { speaker }\right)\end{array}$ \\
\hline 6 & You seem fucking crazy to me & Incongruity & $\begin{array}{l}\text { In the class } \\
\text { (Formal })\end{array}$ & $\begin{array}{l}\text { A distant } \\
\text { relationship } \\
\left(2^{\text {nd }} \text { speaker }\right)\end{array}$ \\
\hline 7 & $\begin{array}{l}\text { If you do not get off my fucking } \\
\text { back, I am gonna shove a box of } \\
\text { chocolate clusters up that tight ass } \\
\text { of yours }\end{array}$ & Incongruity & $\begin{array}{l}\text { In the class } \\
\text { (Formal) }\end{array}$ & $\begin{array}{l}\text { A distant } \\
\text { relationship } \\
\left(2^{\text {nd }} \text { speaker }\right)\end{array}$ \\
\hline
\end{tabular}

